\title{
Prevalence And Intensity of Helminth Infection in Human Immunodeficiency Virus Infected Children in Abakaliki, Ebonyi State, Southeast, Nigeria
}

\author{
Maria Lauretta Orji ${ }^{1}$ nnamdi Benson Onyire ${ }^{1}$, Bede Ibe, ${ }^{2}$ Roland Ibekwe ${ }^{2}$ \\ ${ }^{I}$ Department Of Paediatrics, Federal Teaching Hospital Abakaliki (FETHA), Ebonyi State \\ ${ }^{2}$ Department Of Paediatrics, University Of Nigeria Teaching Hospital, Ituku-Ozalla, Enugu State
}

\begin{abstract}
Infection by soil-transmitted helminth is not opportunistic infection, however, studies among HIV infected patients (adults and children) showed significantly higher prevalence rates of helminthic infection compared to controls.

This study was done to determine the prevalence and intensity of helminthic infection in HIV infected children in Abakaliki. It was a cross sectional study that involved consecutive recruitment of 84 confirmed HIV infected children and equal number of age and gender matched HIV negative children as controls. Stool analysis for both subjects and controls was done, using the Kato-Katz technique. Structured questionnaire was used to obtain socio-demographic information.

The prevalence of intestinal helminthiasis in children infected with HIV in the two study centers was $28.6 \%$ as against $20.2 \%$ observed in controls (difference not significant). Mean parasite intensity of HIV infected subjects was found to be $276.35 \pm 55.34$, which was significantly higher than the mean parasite intensity observed in controls (162.35 \pm 55.29$)$, $(p=0.001)$.

In conclusion, this study noted a higher mean parasite intensity of helminth infection in HIV infected children compared to normal population. Regular de-worming exercise for all children, and in particular HIV infected children, is recommended.
\end{abstract}

Keywords: helminth infection, helminth intensity, Kato-Katz kit, regular de-worming

\section{Introduction}

Helminth infection is one of the most common and neglected diseases affecting more than $30.0 \%$ of the world's population.[1]The majority of helminth infections occur in sub-Saharan Africa, Asia, Latin America and the Caribbean.[2] Helminthiasis is prevalent in these regions because of a combination of economic underdevelopment and conducive climates which are favorable for the development and survival of the larvae of helminths.[1] Intestinal helminth infections affect all age groups, but predominantly children, with pre-school and school age children at highest risk of severe morbidity.[3-5] It was estimated by World Health Assembly (WHA) in 2001 that about 2 billion people were infected by soil-transmitted helminths (S-THs) and schistosomiasis worldwide.[6] The WHA urged member states to recognize the possible synergy in the public health control programs for S-TH, schistosomiasis and other diseases. Considering the new dimension created by HIV epidemic in the same impoverished communities and countries where helminthiasis is hyper-endemic, there is need for synergy in public health program to address this dual epidemic as proposed by the WHA.[6]

Human Immunodeficiency Virus (HIV) infection is a major global health problem and affects all regions of the world.[7-8] Sub-Saharan Africa had a total of 22.5 million people living with HIV, out of which 2.5 million were children less than 15 years, thus carrying the greatest burden of disease with $68.0 \%$ of all people living with HIV residing in the region.[9] HIV causes a spectrum of diseases, from the asymptomatic infection to the symptomatic disease. At the end of this spectrum is the acquired immunodeficiency syndrome (AID).[9-10] In 2009, HIV accounted for 3.6\% and 3.0\% of under-five mortality in sub-Saharan Africa and Nigeria respectively.[11] Nigeria accounted for $30.0 \%$ of the global burden of MTCT of HIV and bore $10.0 \%$ of global paediatric HIV/AIDS burden in the same year.[11-12]

Epidemiological studies, mainly in adults, reported higher prevalence rates of helminth infections in HIV infected patient compared to controls.[13-15] Akinbo et al[13] studied intestinal helminthiasis among adults infected with HIV, they found a significantly higher prevalence rate of helminthiasis in the HIV infected adult compared to the HIV negative controls. Generally, there is paucity of published data on intestinal helminthiasis in HIV infected children in Nigeria. Wagbatsoma et al[16] carried out a cross sectional study on HIV seropositivity and intestinal helminthiasis among children in a tertiary health facility in Benin city, Nigeria. They reported a significantly higher prevalence rate of helminth infection (21.4\%) in HIV infected children compared to controls $(9.6 \%)$. 
This study was aimed at determining the prevalence and intensity of helminthic infection in HIV infected children. It is anticipated that results from this study would improve the management of patients with HIV/helminth co-infection.

\subsection{Study area}

\section{Methodology}

Ebonyi State is located in the rain forest zone, the climate is tropical. The annual rainfall varies from $2,000 \mathrm{~mm}$ in the Southern areas to $1,150 \mathrm{~mm}$ in the north.[17]The temperature throughout the year ranges between $21^{\circ} \mathrm{C}$ to $30^{\circ} \mathrm{C} .{ }^{17} \mathrm{It}$ has two seasons, dry and wet. The dry season lasts from November to March while the rainy season lasts from April to October.[17] It has a total population of 2,173,501 people, majority of which are Igbos.[18]

The study is a prospective hospital based study carried out in two health facilities - Federal Teaching Hospital Abakaliki (FETHA) and Mile Four Maternity and Children Hospital, both located in Abakaliki, the Ebonyi State capital, from July 2013 to October 2013.

The Federal Teaching Hospital Abakaliki (FETHA) operates a provider-initiated HIV testing and counseling (PITC), in which every child that presents at the Children Out-patient Clinic is offered HIV antibody test irrespective of presenting complaint, except on objection by the caregiver, however objection (opt-out) of the caregiver to the screening test does not affect quality of treatment given to the child. Any child who tested positive to the test is referred to the Paediatrics Infection Disease Clinic for further evaluation and management. The Children Out-patient Clinic runs on daily basis with an average patient attendance of 35 patients per clinic day. Mile Four Maternity and Children Hospital was established in 1946. It is a mission hospital

\subsection{Determination of sample size}

Sample size was calculated using the prevalence rate reported by Wagbatsoma et al[16] (21.4\%). A minimum sample size of 84 was obtained. With equal number of age and gender matched controls recruited consecutively from the children out-patient clinic, giving a total of 168 children.

\subsection{Ethical considerations}

Approval from the Health Research and Ethical Committee of FETHA was obtained and permission from the authorities of Mile Four Maternity and Children's Hospital was also obtained before the commencement of study. The study was explained to parents/guardian and only those who gave informed consent were included in the study.

\subsection{Subject selection/stool analysis}

The subjects that have been regular to clinics (in FETHA and Mile Four Hospital) in the past one year prior to the study and newly diagnosed HIV infected children that were referred from the Children Outpatient Clinic within the study period were recruited consecutively until sample size was met. The controls were recruited from the Children Out-patient Clinic of FETHA. At recruitment, a structured questionnaire was used to obtain information. Only one stool sample was required from each subject and control. The stool sample was analyzed using WHO recommended method for stool analysis for helminths -the Kato-Katz technique in the hospital laboratory of FETHA.[19-20]

\subsection{Data analysis}

The data obtained was entered into spread sheet using the Microsoft excel 2007 and the analysis was done using the Statistical Package for Social Science version 19.0. The analysis of data was done by the researcher and the hospital biostatistician. Quantitative variables were summarized using means and standard deviations. Frequency tables and charts were constructed as appropriate. The significance of associations between variables was tested using Chi-square and Fischer's exact tests for comparison of proportions while Student-t test was used for comparison of means. Multivariate analysis of epidemiological variables was determined using Epi Info version 7. The level of statistical significance was achieved if $\mathrm{p}<0.05$

\section{Results}

A total of 84 subjects and 84 controls that met the inclusion criteria were recruited during the study period. Majority were males $49(58.3 \%)$. Male to female ratio was 1.4:1. The age range of participants (subjects and controls) was 2-17 years. The mean age of subjects infected with helminthiasis was $6.10 \pm 3.34$ years while that of controls was $6.85 \pm 3.67$ years. The prevalence rates of intestinal helminth infection were noted to be highest in subjects and controls within the age group 6 -12 years as seen in Table 1.

Age and sex had no significant relationship with prevalence rate of helminth infection as shown in Table 1. Majority of infected subjects $20(40.0 \%)$ and controls 10 (38.5\%) dwelt in the rural area as represented 
in Table 1. A statistically significant relationship existed between residential area and helminth infection for subjects and controls $(\mathrm{p}=0.045$ and 0.005$)$ respectively.

While prevalence rates of helminth infections were low in subjects 7 (16.3\%) and controls $6(11.8 \%)$ that were of upper socio-economic class, subjects belonging to lower socio-economic class (classes IV and V) had the majority of helminth infections in both subjects $17(41.5 \%)$ and controls $11(33.3 \%)$. Socio-economic class significantly influenced prevalence rates of helminthiasis in both subjects $(p=0.028)$ and controls $(0.001)$

The overall prevalence rate of helminthiasis among the study population (subjects and controls) was $24.4 \%$ (41/168). The prevalence of helminthiasis in children infected with HIV was $28.6 \%$ (24/84) compared to $20.2 \%(17 / 84)$ observed in HIV negative controls as shown in Table 2. The difference between the two prevalence rates was not statistically significant $(\mathrm{p}=0.209)$.

Lack of toilet facility was a significant risk factor to acquisition of A.lumbricoides and hookworm infections among subjects, odd ratio (95\%CL) were 20.57 (2.43-174.69), $\mathrm{p}=0.001$ and $6.0(1.61-22.31), \mathrm{p}=0.004$ respectively while lack of foot wear was a significant risk factor to acquisition of hookworm in subjects, odd ratio $(95 \% \mathrm{CL})$ was $0.04(0.01-0.19), \mathrm{p}=0.001$. Lower socio-economic class was a significant risk factor to hookworm acquisition, odd ratio (95\% CL) was 3.75 (0.94-15.00), $\mathrm{p}=0.049$ in subjects as shown in Table 3.

Table 4 shows that the prevalence rate of hookworm infection observed in this study was $19(11.3 \%)$, out of which $12(14.3 \%)$ were from subjects and 7 (8.3\%) was observed in controls, A.lumbricoides was isolated in $16(9.5 \%)$ of the study participants, $9(10.7 \%)$ were from subjects and $7(8.3 \%)$ from controls. The prevalence rate of T.trichiura infection was $5(3.0 \%), 2(2.4 \%)$ from subjects and $3(3.6 \%)$ from controls, while the prevalence rate of S.stercoralis infection in this study was $1(0.6 \%)$. Hookworm was the most prevalent helminth species among the subjects. S.stercoralis was the least isolated helminths in the subjects. No significant relationship was observed between species prevalence rates of helminths and HIV sero-positivity $(\mathrm{p}=0.772)$

The mean egg intensity among infected subjects was $276.35 \pm 55.34$, which is significantly higher than that observed in controls $(162.35 \pm 55.29),(\mathrm{t}=6.514, \mathrm{p}=0.001)$. Table 5 showed the comparison of means of different helminth species between HIV infected subjects and controls. The intensity of infection was light for all species of intestinal helminths in both subjects and controls according to grading of helminths by World Health Organization (WHO). There was no case of multiple infections in either subjects or controls. The intensity range for hookworm was 240- 408 egg per gram (epg), A.lumbricoides was 192-336 epg while that of T.trichiura was 216-240 epg, only a case of S.stercoralis was isolated with an intensity of 216 epg among infected subjects. Among controls, the intensity range for hookworm was 96-288 epg, 120-240 epg for A.lumbricoides and 96-240 epg for T.trichiura. There were statistically significant differences in the mean egg intensities between HIV infected subjects and controls, for the different species of helminth as shown in Table 5

\subsection{Tables}

Table 1: Socio-demographic characteristics of subjects and controls infected with soil-transmitted helminths

\begin{tabular}{|c|c|c|c|c|}
\hline \multirow[b]{2}{*}{ Age (years) } & \multicolumn{2}{|l|}{ Subjects } & \multirow{2}{*}{$\begin{array}{l}\text { Controls } \\
\text { No. tested }\end{array}$} & \multirow[b]{2}{*}{$\begin{array}{l}\text { No. infected } \\
\text { (\%) }\end{array}$} \\
\hline & No. tested & $\begin{array}{l}\text { No. } \\
\text { infected } \\
(\%)\end{array}$ & & \\
\hline$\leq 5$ & 35 & $10(28.5)$ & 35 & $5(14.3)$ \\
\hline $6-12$ & 38 & 11 (28.9) & 38 & $12(31.6)$ \\
\hline$>12$ & 11 & $3(27.2)$ & 11 & $0(0.0)$ \\
\hline Total & 84 & 24 (28.6) & 84 & $17(20.2)$ \\
\hline & $\chi^{2}=0.72$ & $\mathrm{p}=0.696$ & $\chi^{2}=4.78$ & $\mathrm{p}=0.091$ \\
\hline Gender & & & & \\
\hline Male & 49 & 15 (30.6) & 49 & $11(22.4)$ \\
\hline Female & 35 & $9(25.7)$ & 35 & $6(17.1)$ \\
\hline $\begin{array}{l}\text { Total } \\
\text { Rural dwelling }\end{array}$ & $\chi^{2}=0.12$ & $\begin{array}{l}24(28.6) \\
P=0.599\end{array}$ & $\begin{array}{l}84 \\
\chi^{2}=0.74 \\
58\end{array}$ & $\begin{array}{l}17(20.2) \\
\mathrm{P}=0.285\end{array}$ \\
\hline $\begin{array}{l}\text { Rural } \\
\text { Social class }\end{array}$ & $\begin{array}{l}50 \\
\chi^{2}=3.06\end{array}$ & $\begin{array}{l}20(40.0) \\
\mathrm{P}=0.045\end{array}$ & $\begin{array}{l}26 \\
\chi^{2}=5.41\end{array}$ & $\begin{array}{l}10(38.5) \\
\mathrm{P}=0.005\end{array}$ \\
\hline Upper & 43 & $7(16.3)$ & 51 & $6(11.8)$ \\
\hline Lower & $\begin{array}{l}41 \\
\chi^{2}=3.87\end{array}$ & $\begin{array}{l}17(41.5) \\
\mathrm{P}=0.028\end{array}$ & $\begin{array}{l}33 \\
\chi^{2}=6.43\end{array}$ & $\begin{array}{l}11(33.3) \\
\mathrm{P}=0.001\end{array}$ \\
\hline
\end{tabular}


Table 2: Distribution of helminth infection between subjects and controls

\begin{tabular}{|l|l|l|}
\hline & HIV sero-positivity & \\
\hline Presence of helminth ova & $\begin{array}{l}\text { Subjects (positive) } \\
(\%)\end{array}$ & $\begin{array}{l}\text { Controls (negative) } \\
(\%)\end{array}$ \\
\hline Infected & $24(28.6)$ & $17(20.2)$ \\
\hline Not infected & $60(71.4)$ & $67(79.8)$ \\
\hline Total & $84(100.0)$ & $84(100.0)$ \\
\hline
\end{tabular}

$\chi^{2}=1.58 \quad \mathrm{p}=0.209$

Table 3: Multivariate analysis for the association between the epidemiological variables and A. lumbricoides

\begin{tabular}{|c|c|c|c|c|}
\hline Variables & $\begin{array}{l}\mathrm{AL} \\
\text { Odd ratio }(95 \% \mathrm{CL})\end{array}$ & $P$ & $\begin{array}{l}\text { HW } \\
\text { Odd ratio(95\%CL) }\end{array}$ & $P$ \\
\hline $\begin{array}{l}\text { Hand washing } \\
\text { practices } \\
\text { Water \&soap } \\
\text { Water only } \\
\text { No handwash }\end{array}$ & $\begin{array}{l}1.00 \\
0.18(0.04-0.79) \\
0.46(0.05-3.96)\end{array}$ & $\begin{array}{l}0.014 \\
0.471\end{array}$ & $\begin{array}{l}1.00 \\
0.29(0.01-2.45) \\
0.17(0.03-0.99)\end{array}$ & $\begin{array}{l}0.232 \\
0.032\end{array}$ \\
\hline $\begin{array}{l}\text { Social class } \\
\text { Upper } \\
\text { Lower }\end{array}$ & $\begin{array}{l}1.00 \\
1.36(0.34-5.44)\end{array}$ & 0.668 & $\begin{array}{l}1.00 \\
3.75(0.94-15.00)\end{array}$ & 0.049 \\
\hline $\begin{array}{l}\text { Source of drinking } \\
\text { water } \\
\text { Tap } \\
\text { Bore-hole } \\
\text { Others } \\
\end{array}$ & $\begin{array}{l}1.00 \\
1.55(0.35-6.81) \\
0.81(0.09-7.21)\end{array}$ & $\begin{array}{l}0.557 \\
0.850\end{array}$ & $\begin{array}{l}1.00 \\
0.93(0.22-3.80) \\
2.20(0.38-12.44)\end{array}$ & $\begin{array}{l}0.919 \\
0.362\end{array}$ \\
\hline $\begin{array}{l}\text { Type of toilet } \\
\text { facility } \\
\text { Water closet } \\
\text { Pit latrine } \\
\text { No toilet facility }\end{array}$ & $\begin{array}{l}1.00 \\
0.57(0.11-2.95) \\
20.57(2.43-174.69)\end{array}$ & $\begin{array}{l}0.500 \\
0.001\end{array}$ & $\begin{array}{l}1.00 \\
1.06(0.29-3.90) \\
6.0(1.61-22.31)\end{array}$ & $\begin{array}{l}0.924 \\
0.004\end{array}$ \\
\hline $\begin{array}{l}\text { Foot wear use } \\
\text { Yes } \\
\text { No }\end{array}$ & $\begin{array}{l}1.00 \\
0.64(0.11-3.52)\end{array}$ & 0.602 & $\begin{array}{l}1.00 \\
0.04(0.01-0.19)\end{array}$ & 0.000 \\
\hline $\begin{array}{l}\text { Residential area } \\
\text { Urban } \\
\text { Rural }\end{array}$ & $\begin{array}{l}1.00 \\
2.09(0.52-8.47)\end{array}$ & 0.290 & $\begin{array}{l}1.00 \\
0.11(0.01-0.88)\end{array}$ & 0.014 \\
\hline
\end{tabular}

$\mathrm{AL}=$ A.lumbricoides, $\mathrm{HW}=$ Hookworm

T.trichura and S.strongyloides were not assessed because of very small prevalence rates

Table 4: Prevalence and types of helminth ova seen in examined stool sample of subjects and controls

\begin{tabular}{|l|l|l|l|l|l|}
\hline & $\begin{array}{l}\text { Hookworm } \\
(\%)\end{array}$ & $\begin{array}{l}\text { A.lumbricoides } \\
(\%)\end{array}$ & $\begin{array}{l}\text { T.trichiura } \\
(\%)\end{array}$ & $\begin{array}{l}\text { S.stercoralis } \\
(\%)\end{array}$ & $\begin{array}{l}\text { Total } \\
\text { population } \\
(\%)\end{array}$ \\
\hline Subjects & $12(14.3)$ & $9(10.7)$ & $2(2.4)$ & $1(1.2)$ & $84(50.0)$ \\
\hline Controls & $7(8.3)$ & $7(8.3)$ & $3(3.6)$ & $0(0.0)$ & $84(50.0)$ \\
\hline Total & $19(11.3)$ & $16(9.5)$ & $5(3.0)$ & $1(0.6)$ & $168(100.0)$ \\
\hline
\end{tabular}

Fischer's exact $=1.660, p=0.772$

Table 5: Comparison of intensity of helminthiasis between subjects and controls

\begin{tabular}{|l|l|l|l|c|}
\hline \multirow{2}{*}{$\begin{array}{l}\text { Helminth ova } \\
\text { seen }\end{array}$} & \multicolumn{2}{|c|}{$\begin{array}{c}\text { Intensity of helminthiasis } \\
\text { (Mean egg count } \pm \text { SD) }\end{array}$} & \\
\cline { 2 - 5 } & $\begin{array}{l}\text { Infected subjects } \\
(\mathrm{n}=24)\end{array}$ & Infected controls (n=17) & t-test & P value \\
\hline Hookworm & $292.00 \pm 62.35$ & $112.00 \pm 13.85$ & 7.450 & 0.001 \\
\hline A.lumbricoides & $270.89 \pm 43.20$ & $164.57 \pm 62.63$ & 6.301 & 0.001 \\
\hline T.trichiura & $228.00 \pm 16.97$ & $184.00 \pm 62.99$ & 2.670 & 0.036 \\
\hline
\end{tabular}




\begin{tabular}{|l|l|l|l|}
\hline S.stercoralis & 216 & \\
\hline
\end{tabular}

\section{Discussion}

The prevalence rate of helminthiasis observed among subjects in this study was $28.6 \%$ which was consistent with that reported by Wagbatsoma et al,[16] (21.4\%) Modjarrad et al[21] (24.9\%) and Abaver et al[15] $(24.7 \%)$ but lower than that reported by Hailemariam et al[14] $(52.6 \%)$. The lower prevalence rate reported in this study when compared to that by Hailemariam et al[14] may be because majority of the subjects $(86.9 \%)$ in index study were on HAART, which has been reported to improve immunological state and protect against helminth infection.[22-23] The prevalence rate of helminthiasis $(20.2 \%)$ observed among the HIV negative children in this study was within the range of prevalence rates of helminthiasis in Nigerian children (9.1\% to $95.7 \%)$.[24-26]

The pattern of helminthiasis among study participants showed that children above 12 years of age (post-primary school age) had the lowest prevalence rate of helminthiasis in both subjects and controls. This agreed with that reported by Wagbatsoma $e t a l,[16]$ who also observed the least prevalence of helminthiasis in children above primary school age. Reason being that children above 12 years may better understand the need for and practice of personal and environmental hygiene compared to younger age groups. There was no significant relationship between sex and helminth infection in this study.

Although the prevalence of helminth infection was higher in HIV infected subjects compared to controls, there was no significant relationship between prevalence rate of helminthiasis and HIV seropositivity. This was consistent by findings by Abaver et al,[15] in an adult study of 84 HIV infected subjects and 34 controls. The above findings differed from that reported by Wagbatsoma et al[16] and Akinbo et al[13] who used larger sample sizes. Differences in results may be attributed to differences in sample sizes.

Studies by Akinbo et al[13] (in adults) and Wagbatsoma et al[16] (in children) reported higher prevalence rates of A.lumbricoides in both subjects and controls. This is contrary to what was observed in index study where hookworm infection predominated, although prevalence rate of A.lumbricoides was also higher in subjects compared to controls. This may be related to a combination of lack of foot wears to school, open defaecation and lower socio-economic class that were predominant in subjects compared to controls, corroborating the fact that HIV/helminth co-infection is more in economically disadvantaged population. This was in keeping with findings by Walson et al.[27]

A higher prevalence rate of helminth infection was observed in HIV infected children (28.6\%) in this study compared to that observed in controls (20.2\%). This was similar to that reported by Wagbatsoma et al.[16] The intensity of helminth infection in HIV infected subjects was more than that in controls. This suggests that HIV seropositivity influences the multiplication (intensity) of helminth infection. This may be because in HIV infected individuals, immune activated CD8 T-cells and natural killer (NK) cells secrete IFN- $\gamma$ which inhibits Th2 cell production and Th2 cytokines.[12,28] This immune alteration may have compromised the control of helminths thereby allowing the helminths to flourish in the presence of HIV infection. This was consistent with the findings by Wagbatsoma et al[16] who reported a significant difference between intensity of helminth in HIV infected children compared to controls.

In conclusion, although socio-demographic factors influenced the prevalence of helminth in HIV positive children and controls, HIV sero-positivity influenced the intensity of helminth infections in infected host. Routine (3-monthly) de-worming is therefore recommended for all HIV infected patients.

\section{Conflict Of Interests}

article.

There is no conflict of interests among authors. All the authors contributed in different aspects of the

\section{References}

[1]. Enobong I, Anochie CI. Intestinal helminthic Infection. In: Azubuike JC, Nkanginieme KEO eds. Paediatric and Child Health in a Tropical Region, $2^{\text {nd }}$ edition. African Educational Services, Owerri, Nigeria. 2007; 438-44.

[2]. De Silva NR, Brooker S, Hotez PJ, Montresor A, Engels D, Savioli L. Soil transmitted infections: Updating the global picture. Trends Parasitol 2003; 19:547-551.

[3]. Oguanya FC, Okogun GRA, Akhile AO, Eloka CCV, Okoro CJ, Okpe AL. Prevalence of Soil-Transmitted Helminth infections among public primary school pupils in Ekpoma, Edo State, Nigeria. I J Comm. Res. 2012; 1:30-34.

[4]. Shehu MM, Kabiru A, Abubakar U, Mohammed K. Prevalence of intestinal helminth infection among school children in relation to occupation of parents and toilet facilities in Manu L.G.A, Zamfara State. J Bio Agric Healthcare. 2013;3: 87-90.

[5]. Odikamnaro OO, Ikeh IM. Prevalence of common intestinal nematode infection among primary school children in Kpirikpiri community of Abakaliki, Nigeria. Niger. J Parasitol. 2004; 24:71-79.

[6]. Finchman JE, Markus MB, Adams VJ. Could control of soil transmitted helminthic infections influence the HIV/AIDS pandemic? Acta Tropica 2003; 86: 315-33

[7]. UNAIDS/WHO. Report on the global HIV/AIDS epidemics. Geneva; 2010. Available at http://www.unaids org/global_report htm. Accessed on 05- 10- 2012 
[8]. Weiss RA, Dalgleish AG, Loveday C, Pillay D. Human immunodeficiency viruses. In: Zuckerman AJ, Banatvala JE, Pattison JR, Griffiths PD, Schoub BD (eds). Principles and Practice of Clinical Virology. $5^{\text {th }}$ edition. Chichester: John Wiley and Sons Ltd. 2004: 721-57.

[9]. Tindyebwa D,Kayita J,Musoke P, Eley B, Nduati R, Coovadia H. In: Tindyebwa D, Kayita J, Musoke P, Eley B, Nduati R, , Tumwesigye N, Mwansambo C, Mbori-Ngacha D, Kieffer MP, eds. Handbook on Paediatric AIDS in Africa. Africa Network for the Care of children affected by AIDS. $2^{\text {nd }}$ edition. Uganda: Family Health International. 2011; 3-26.

[10]. Owerri.2007; 643 Eneh AUP. Human Immunodeficiency Virus (HIV) infection. In: Azubuike JC, Nkanginieme KEO, eds. Paediatrics and Child Health in a tropical region. $2^{\text {nd }}$ edition. African Educational Services -54.

[11]. National Guideline for Paediatric HIV and AIDS, Treatment and Care. Federal Ministry of Health of Nigeria. $2^{\text {nd }}$ edition. 2011; 943.

[12]. Del Prete G, Maggi E, Romagnani S. Human Th1 and Th2 cells: functional properties, mechanism of regulation and role in disease. Lab Invest 1994; 70: 299-306.

[13]. Akinbo FO, Okika CE, Omeregie R. Prevalence of intestinal parasitic infection among HIV patients in Benin City, Nigeria. Libyan J Med 2010; 5:5506. Doi: 10.3402/ ijm.v5i0.55060.

[14]. Hailemariam G, Kassu A, Abebe G, Abate E, Damte D, Mekonnen E et al. Intestinal parasitic infections in HIV/AIDS and HIV seronegative individuals in a Teaching Hospital, Ethiopia. Ethiopian J Infect Dis. 2004; 57: 41-43.

[15]. Abaver DT, Nwobegahay JM, Goon DT, Iweriebar BC, Anye DN. Prevalence of intestinal parasitic infections among HIV/AIDS patients from two health institutions in Abuja, Nigeria. Afr Health Sci. 2011; 11: S24-S27.

[16]. Wagbatsoma VA, Ogbaini E, Esene H, Ibadin K. HIV Sero-positivity and intestinal helminthiasis among children in a Tertiary health facility in Benin City, Nigeria. Niger. Med. Pract. 2010; 57:10-16.

Weather/ climate of Ebonyi state. Available at www.cometonigeria.com/search-by/ebonyi-state. Accessed on the 27/04/14.

[17]. Federal Republic of Nigeria. 2006 population and housing census of Nigeria. Federal Republic of Nigeria official gazette. Lagos 2007; 94.

[18]. Available at www.census.gov/geo/reference/urban. Accessed on the 16/04/14.

[19]. Montresser A, Crompton DWT, Hall A, Bundy DAP, Savioli L. Guidelines for the eradication of soil transmitted helminths and schistosomiasis at community level. Schistosomiasis and Intestinal Parasite Unit, division of control of Tropical disease. World Health Organization Geneva. WHO/CTD/SIP 1998; 1-48.

[20]. WHO. Prevention and control of Schistosomiasis and Soil-transmitted helminthiasis: report of a WHO Expert Committee. WHO Tech Rep Ser. 2002; 912: 1-57.

[21]. Modjarrad K, Zulu I, Redden DT, Njobvu L, Freedman DO, Vermund SH. Prevalence and predictors of intestinal helminth infection among Human Immunodeficiency Virus type 1 infected Adults in an urban setting. Am J Trop Med Hyg 2005; 73: 777- 82

[22]. Bachur TP, Vale JM, Coelho IC, Queiroz TR, Chaves Cde S. Enteric infections in HIV/AIDS patients before and after the highly active antiretroviral therapy. Braz J Infect Dis. 2008; 12: 115-122.

[23]. Assefa S, Erko B, Medhin G, Assefa Z, Shimelis T. Intestinal parasitic infections in relation to HIV/AIDS status, diarrhea and CD4 T-cell count. BMC Infect Dis. 2009; 9:155

[24]. Enimien OJ, Fana SA, Emmanuel WB. Intestinal helminthic infection in Numan (North East Nigeria) I J Innov. Appl. Studies. 2014; 5: 102-5.

[25]. Oyibo PG, Juneke C, Oyibo IA. Efficacy of single dose antihelminthic Treatment against Soil-Transmitted Helminth infections and schistosomiasis among school children in selected rural communities in South-East Nigeria. J Comm. Med. Prim Healthcare. 2011; 23:98-104

[26]. Anosike JC, Zaccheaus VO, Adeiyongo CM, Abanobi OC, Dada EO, Oku EE. Studies on the intestinal worm (Helminthiasis) infestation in a rural community in North-Central Nigeria. J Appl. Sci. Environ. Mgt. 2006; 10: 61-6.

[27]. Walson JL, Stewart BT, Sangare L, Mbogo LW, Otieno PA, Piper BKS, et al. Prevalence and correlates of Helminth coinfection in Kenyan HIV-1 infected adults. PLoS Neg1 Trop Dis 2010;4: e644.

[28]. Del Prete G, Maggi E, Romagnani S. Human Th1 and Th2 cells: functional properties, mechanism of regulation and role in disease. Lab Invest 1994; 70: 299-306. 